\title{
PRECONDITIONS AND PRIORITY DIRECTIONS OF THE REFORM OF THE SYSTEM IN NATIONAL HIGHER EDUCATION
}

\section{Orshanskiy L.V.}

\section{INTRODUCTION}

With the adoption of the Laws of Ukraine "Education Law" (2017) ${ }^{1}$ and "Higher Education Law" (2014) $)^{2}$, an active process of transformation of this important industry began in the context of European integration processes and prospects. In order to implement a strategic course on the entry of Ukraine into the European educational space, the main directions of educational, scientific and cultural integration have been identified, the mechanisms of implementation of European norms and standards in higher education have been identified, etc. As a result, these areas and mechanisms should work to enhance the European cultural identity of Ukrainians and create a pan-European intellectual and educational environment in Ukraine. However, despite the modern vector of higher education development, which leads to a new sociopolitical paradigm, this branch, unfortunately, does not provide the necessary quality that necessitates its reforming, that is, deliberately regulated improvement and intensification of educational and scientific processes.

With the help of existing statistical data, we will try to analyze the current state and problems of the Ukrainian higher education system, which experienced systemic structural changes, as well as to determine the preconditions and priority directions of the reform of the system in national higher education.

\footnotetext{
1 Про освіту: Закон України від 05.09.2017 р.№ 2145-VIII. URL : http://zakon.rada.gov.ua/laws/ show/2145-1

2 Про вищу освіту. Закон України № 1556-VII від 01.07.2014. URL : http://zakon4.rada.gov.ua/laws/ show/1556-18
} 


\section{Current state of higher education in Ukraine and the problems of its reformation}

According to the State Statistics Service of Ukraine ${ }^{3}$, since the 1990s, there has been a steady increase in the number of institutions of higher education (HEI). So, if in 1991-1992 the year in Ukraine there were 742 institutions of secondary specialized and vocational education and 149 HEI, then in the "peak" 2006-2007 there were 570 colleges, technical schools, colleges, lyceums and 350 universities, academies, institutes. Therefore, the number of HEI of I - II levels of accreditation, for the last 16 years, decreased by 172 establishments $(23,2 \%)$, while the number of HEI of III - IV accreditation levels increased by 201 (235\%).

Before putting "Higher Education" law into action, on August 1st, 2014, in Ukraine, there were generally 803 state, communal, joint-stock, and private self-employed I - IV accreditation levels, among which: 198 universities, 62 academies, 83 institutes, 245 colleges, 97 technical schools, 117 vocational schools and 1 conservatory (Fig. 1). The Ministry of Education and Science in 2014 transferred from the higher vocational class to more than one hundred educational institutions. At the beginning of 2016 in Ukraine there are about 659 HEI (371 establishments of education of the I - II levels of accreditation, 288 - III - IV accreditation levels) and their further optimization (branch reduction, consolidation, etc.) is carried out.

A significant demand for prestigious university education in the first place has created a paradoxical situation when, against the backdrop of the socio-economic crisis of the mid-1990s, a sharp decline in the population and the closure of industrial enterprises that needed skilled workers and engineers, the number of students studied at the HEI of different levels of accreditation has increased almost three times: from 1638,3 thousand people in 1990-1991 years up to 2813,8 thousand in 2007-2008 year. Then there was a sharp decrease in the number of students, which is related exclusively to demographic and socio-economic problems. At present, 1605,300 students study at the I - IV levels of accreditation (Fig. 2).

\footnotetext{
3 Державна служба статистики України : Вищі навчальні заклади. URL : http://www.ukrstat.gov.ua/ operativ/operativ2005/osv_rik/osv_u/vuz_u.html
} 


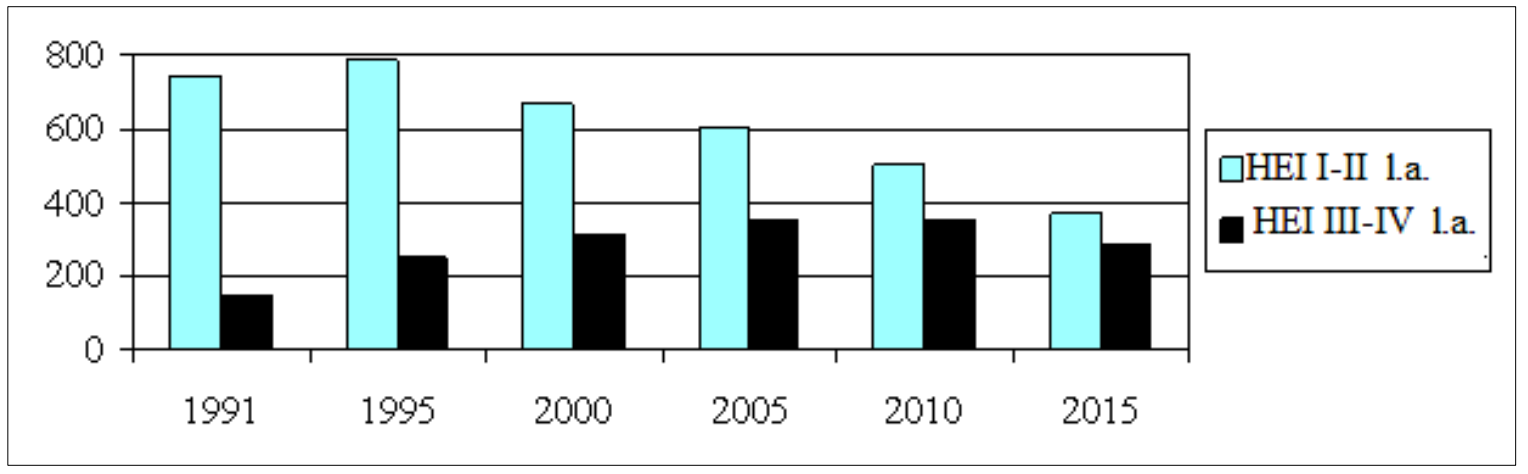

Fig.1 The number of educational institutions

I-V levels of accreditation in UA

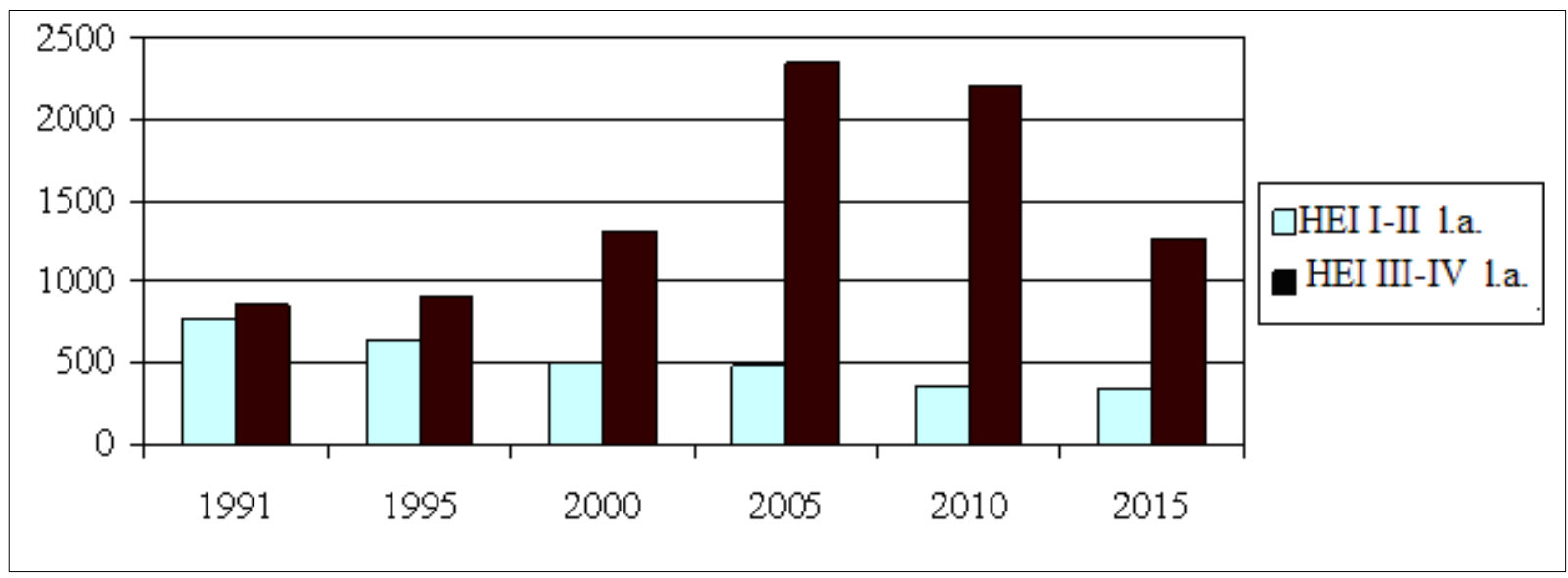

Fig. 2. The number of students belonged to educational institutions I-IV of accreditation

So, nowadays the number of vocational education institutions has decreased by half from 742 to 371, whilst the number of universities and other types of HEI in the past 25 years has increased by $193 \%$. Such an uncontrolled increase in the number of HEIs, as well as the demographic challenge of Ukrainian society, led to the proportionality of the number of educational places in higher educational institutions and the number of graduates of secondary schools (Fig. 3). There was a total transition to a massive, universally accessible higher education, which for citizens, supposedly, was a "mandatory attribute". Beginning from 2006-2007 the number of enrolled students almost every year exceeded the number of those who in the same year completed secondary education. That is, 
consecutive for the ninth year, starting in 2007, university education in Ukraine has become a kind of continuation of the school, one of the mechanisms of social protection of youth. This could be seen as a positive fact, if not a number of circumstances of great concern.

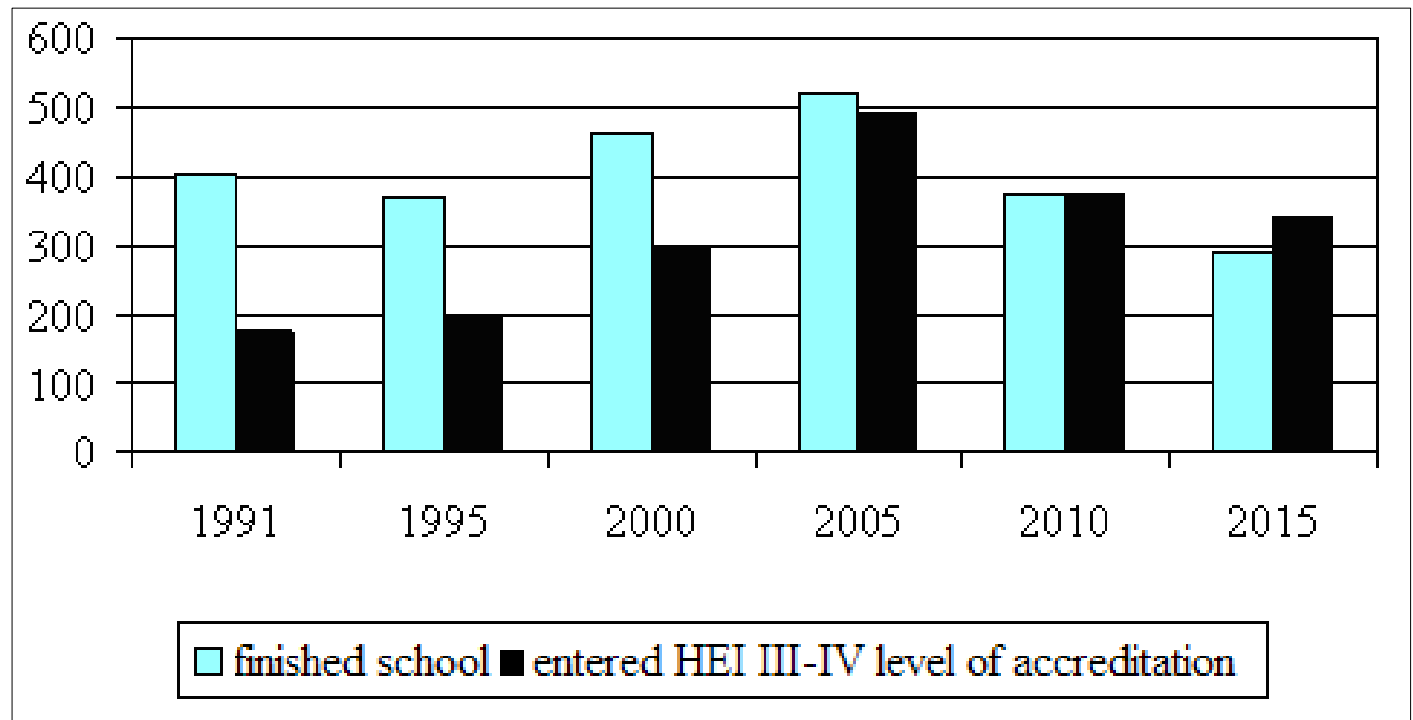

Fig. 3 The number of students of schools who received certificates of full secondary education and students who entered HEI

Most national HEIs created during the period of uncontrolled growth, do not have adequate material and technical resources for the qualitative implementation of the educational process, they virtually have no library funds, the state of such educational institutions consists mainly of detached workers, mostly teachers of "neighboring" state institutions or even teachers of secondary schools. About scientific, pedagogical schools, directions of fundamental and applied research, long-term educational traditions in such "universities" language is not discussed at all. Of course, the state granted the right to get profit on education, and nobody canceled it yet, but the requirements for the quality of higher education should be the same for educational institutions of all forms of ownership.

With the transition of society to market relations, institutions of professional and higher education become the subjects of a market economy. In everyday colloquial vocabulary, instead of words "education 
and training" the term "educational services" is increasingly used, and the success of higher education is considered through the prism of market relations, reloaded the fund of development. It should be acknowledge that in the gross value added by Ukraine in 2012, the share of the education sector was $6,2 \%$ (UAH 75,1 billion), twice the share of construction and approaching the indicator of extractive industry. However, the formed structure of these market relations of higher education and society is of some concern. Over the past decade, the proportion of students in stateowned non-state assets, based on contract, has an increased from $21,4 \%$ to $56,2 \%$. This way, in 2013 - 2014 the HEIs of IV - IV accreditation levels, using the state budget funded 750,4 thousand people, local budgets formed - 18,8 thousand people, natural and legal persons - 954,5 thousand people ${ }^{4}$. It is understandable and logical to see the interest of HEI in the students' recruitment based on a contract, as they load up the extrabudgetary fund, creating additional opportunities for decent wages, bonus of scientific and pedagogical workers, infrastructure development, updating of material and technical base, etc. On the other hand, such an increase in interest for recruiting on a paid form of studying leads to a decrease in quality of the students' contingent. While forming educational groups, most universities makes no differentiation of students' groups depending on the form of payment. Taking into an account the substantially lower requirements for students with paid forms of education, one can speak about reducing the working capacity of the academic group as a whole, as well as the motivation and ability to study for each individual student.

Another problem that causes concern to Ukrainian society, which showed a desire to join the EU in the nearest future, is the lack of HEI being prepared for the internationalization of higher education. Although our country joined the Bologna process, which initiated the structural modernization of national higher education systems, putting into practice this did not lead to the effective integration of the home educational system

\footnotetext{
${ }^{4}$ Вища освіта України. Центр міжнародних проектів НДІ прикладних інформаційних технологій «Свро Освіта». URL : http://www.euroosvita. net/prog/print.php/prog/print
} 
into the European scientific and educational space. On the other hand, recently a number of trends in the transformation of specialists in higher education have been implemented, namely: ensuring the transparency of educational programs; creating conditions for comparing educational programs in different universities and in different European countries; implementation of the European Credit Transfer and Transfer System (ECTS) as a basic tool for enrollment of academic disciplines, developed by students at other universities, etc. Yet, it should be acknowledged that the system of academic mobility has not yet begun, which enables students and teachers to "move" from one form of HEI into another one, gaining an access to new quality educational programs, courses, research activities, improve their foreign language skills.

As a result, today there are a number of powerful state "players" capable of competing in the world market of educational services. So, if in the world ranking of the level of general education published by the International Organization for Economic Cooperation and Development, Ukraine in 2015 ranked rather high of 38th place, then according to Quacquarelli Symonds' version, in the ranking of the 1000 best universities in the world (QS World University Rankings) in 2016 only six national universities were included - V.N. Karazin Kharkiv National University (382th place), Taras Shevchenko National University of Kyiv (within the limits of 431-440 places), National Technical University of Ukraine "Igor Sikorsky Kyiv Polytechnic Institute" (within 551-600 places), Donetsk National University, The National Technical University "Kharkiv Polytechnic Institute" and Sumy State University (below 701 places). This doesn't mean strengthening the position of Ukraine in the international market of educational services, but on the contrary - the loss of positions on its own national market, due to the desire of young people to immediately study in prestigious higher education of other states. For example, in 2015, more than 20,000 university entrants went to study in Poland; more than half of Ukrainians with higher education do not work according to their specialty, and every third graduate changes his/her profession immediately after 
graduating. Today in Ukraine there are officially about 1.8 million unemployed, more than $80 \%$ of them are specialists with higher education.

Another consequence of a spontaneous formation of the market educational services is unjustifiably high graduation figure of specialists in socio-economic and humanitarian fields. Students' contingent analysis doesn't demonstrate the choice in favor of social, pedagogical, agrarian, engineering or natural sciences, which in its turn lays the foundation of innovation development of industry and society. There is an abundance of "office" workers whilst the apparent shortage of workers, providing a "meaningful" component of home economy. An irony is popular a popular saying that soon managers will have no one to administer, and there will be none left who needs lawyers' defense.

Today, considering relatively young economy market of Ukraine, there is no effective and efficient mutual regulation of queries and offers of labor markets and educational services. This, of course, can not but affect the situation in the field of employment. It seems that nowadays, choosing training in the areas of "Humanities", "Management", "Jurisprudence" and others, entrants and their parents in advance "reserve" a place in the queue at the employment centers. Therefore, special efforts of the state are required to streamline the structure of the directions of training specialists, its harmonization with the needs of the economy and society. Such measures are impossible without a broad vocational guidance work aimed at shaping the needs of a young person to realize their potential in the field of promising areas of production and services that are characterized by the innovative nature of development.

Modern innovative economy, based on high technologies and intellectual work, requires specialists with different levels of competence, which is being prepared within the framework of graduate education. The introduction of a three-tier system of higher education (bachelor, master, doctor of philosophy) provides conceptually new approaches to the formation of the content of education, the application of productive didactic methods and technologies for the organization, implementation and quality control of education, the introduction of components of the 
innovative educational model. It is possible to discuss the appropriateness of certain actions of the state, but the transition to multi-level higher education is a systemic action with far-reaching consequences for the educational sector and the country as a whole, given the European integration hopes. Therefore, the responsibility for the correctness and timeliness of the steps taken by the state, HEI and each of its scientific and pedagogical worker is extremely high.

Obviously, one of the most important factors in the effective functioning of higher education, its successful reformation is providing qualified staff workers. Today, the situation in this area is also quite wellfounded under the concern. According to statistics for 2013-2014 the number of scientific and pedagogical workers of the III-IV level of accreditation was 158,9 thousand people, including more than 71,4 thousands of candidates of sciences and 14,4 thousands of doctors of science, 48 thousands of docents and 12,7 thousands of professors ${ }^{5}$. The analysis of statistical data shows that the increased volume of educational services provided by the higher school is supported practically by the same number of teaching staff as at the end of the twentieth century. Significantly was increased the number of students, who belonged to the unit of scientific and pedagogical staff of scientists with degrees of candidates and doctors of sciences. Although the number of professors' teaching staff of the Defense Forces of Ukraine, which received academic degrees and titles, has increased significantly, at the same time, their average age has increased as well. In this context, it is worth paying attention to the statistical study of quantitative and qualitative indicators of the professors' teaching staff, conducted by A. Makarenko. According to the statistics provided by it, the largest number of teachers having a degree is between the age of 51 and 60 years old. In particular, in 2010, the average age of instructors was 45,7 years old, which is with $26,2 \%$ of faculty graduates reaching middle aged over 50 years old. The average age of candidates of sciences, associate professors working on the positions of the heads of

\footnotetext{
5 Вища освіта України. Центр міжнародних проектів НДІ прикладних інформаційних технологій «Євро Освіта». URL : http://www.euroosvita. net/prog/print.php/prog/print
} 
departments, reached 48,9 years old, and doctors of sciences, professors 56,5 years old $^{6}$. The situation with the middle age of scientific and pedagogical workers has changed only in the direction of its increase over the last two years. This is a rather alarming signal, as it shows the lack of influx of creative young people in the educational sector, the loss of motivation for scientific and pedagogical activity.

The next problem of today's higher education is the insufficient level of personnel reserve due primarily to low wages. According to the State Statistics Service, education is in the top five lowest paid state industries ${ }^{7}$. Thus, the average salary in education in August 2015 amounted to $3542 \mathrm{UAH}^{8}$, which at that time amounted to about \$130. At the same time, it should be pointed out that although the government tried to solve this problem by raising salaries to teachers in 2017 by $50 \%$ and another try by $25 \%$ - in 2018 , however, inflationary processes in the economy virtually dampened these efforts. As for university teachers, over the last past 5 years, their salaries have been raised by $20 \%$ only in early 2019 . Instead, according to an expert survey entitled "The Right to Education and Education Rights" of the European Research Association, conducted with the company InMind in June 2018, where 32\% of teachers performed free overtime work, and $44 \%$ of instructors had experience in exceeding the maximum academic, scientific and methodological load ${ }^{9}$. Obviously, a young teacher who has a difficult path to an associate professor or professor still has to go through, solving a number of home problems (buying housing, creating and maintaining a young family, etc.), such income levels and increased demands become unattractive.

Another important issue of higher education is the multiple employment of a teacher, which is implemented in a variety of forms: a

\footnotetext{
${ }^{6}$ Макаренко А. Ю. Кадровий аспект проблеми формування ІКТ-компетентності викладачів ЗВО. Наукова скарбниия освіти Донеччини. 2013. № 1 (14). С. 85.

7 Державна служба статистики України : Вищі навчальні заклади. URL : http://www.ukrstat.gov.ua/ operativ/operativ2005/osv_rik/osv_u/vuz_u.html

8 Зарплата українських вчителів - одна 3 найнижчих у світі URL : http://www.unian.ua/society/838832zarplata-ukrajinskih-vchiteliv-odna-z-naynijchih-u-sviti.html

${ }^{9}$ Право на освіту та права освітян: теорія і практика в Україні: аналітичний звіт за результатами громадського моніторингу. URL : http://eura.org.ua/ wp-content/uploads/2010/01/ERA_Vidrodzhannya_ Право-на-освіту-та-права-освітян_Аналітичний-звіт_-червень-2018.pdf
} 
combination of work in several universities and the simultaneous conduct of numerous courses, tutoring, scientific and practical activities. Such activities as many others are not related to their profession, but have become for teachers a source of additional income, even sometimes - the main source income. The multiple work of the teacher, the long work over legislative norms depletes, leads to psychological overloads, increase in the cost of teaching work, which are not compensated by the appropriate remuneration. As a result, the motivation and quality of the teacher's work decreases at their main place of work in which is HEI. This state of affairs testifies to the low level of prestige of scientific and pedagogical activity of our society. Reducing the motivation of young scientists to come to the educational sector with a low pay for a teaching job inevitably affects the number and quality of the contingent of applicants enrolled in the specialties that serve this public sector of the economy.

The following prerequisites should be created to solve the above mentioned problems and to successfully reform in higher education:

- firstly, the high level of development of pedagogical science, the formation of the psycho-pedagogical community, its interaction with representatives of related sciences, the humanistic nature and practical orientation of state educational thought, its orientation towards ensuring the unity of education, education and development;

- secondly, the development of scientific research in high school, the successful methodology of training scientific and pedagogical staff, the existence of justified forms of integration of educational and scientific processes;

- thirdly, the application in domestic higher education of effective innovations in the content, methodological and organizational nature, as well as the fundamental possibility of their dissemination through statetargeted programs and training system of scientific and pedagogical workers and university managers. 
Based on the analysis of normative legal materials, literary sources, statistical data and practical experience, we have identified the priority directions of the reform of the national university education:

1)ensuring equal opportunities for obtaining high-quality higher education by different groups of the population;

2) improvement of the educational environment, creation of proper conditions for education at all levels;

3) practical implementation of the idea of "learning throughout life";

4) decentralization of the system of higher education and providing real autonomy of HEI;

5) optimization of the state order for the training of specialists with higher education in accordance with the real needs of the state and private sectors of the national economy;

6) implementation of the principle of student-centered learning;

7) sustainable integration of training and research;

8)further internationalization and deepening the mobility in educational and research activities;

9) extending the rights, freedoms and autonomy of universities;

10)implementation of cooperation in the system "university production";

11)quality control of higher education according to European level;

12)decent wages and social protection of scientific and pedagogical workers.

13) the possibility of diverse student and teacher's development;

14)improvement of the mechanisms and infrastructure for raising professional skills and teaching staff retraining;

15)the creation of advanced educational and methodological support of modern material and technical base.

\section{The basic principles of the University's innovative educational policy}

Today the essence of the University's educational policy is to provide these fundamental directions in a clear and transparent form for all 
scientific and pedagogical workers: as a set of tasks, coordinated from all kinds of resources and mechanisms, while giving the freedom of choice for teachers and the administration to perform actions for the implementation of new ideas. It should be borne in mind that reforming the educational sector, improving the educational policy can only be achieved by involving as many as possible experienced teachers, managers and active students in this process, which requires the development of a certain corporate culture and fundamentally new thinking.

To form such thinking among the entire staff of the University in order to achieve the goal is one of the main objectives of innovative educational policy, which is developed on the basis of the unified basic principles proposed by V. Astakhova ${ }^{10}$ :

1. The principle of social determination - requires, first and foremost, awareness of each subject of the educational process of the main social tasks put forward by society and the state at the given historical moment before the system of higher education. Only based on this it is possible to define a specific niche of the university, its strategic and tactical tasks, the content of educational activities, forms and methods of organization of educational work.

2. The principle of social partnership - involves a radical change in the functional characteristics and target directions of education, the formation of a new system of relations between government, business, students, parents, employers and educational institutions, which will enhance the quality of professional training.

Unfortunately, social partnership is currently only being formed, therefore, it does not reveal systemic character and requires comprehensive study and testing of implementation mechanisms. However, some of its trends are already quite clear. For example, the transition from the formalcompulsory model of relationships between partners in the system of higher education to the initiative-humanistic, oriented towards the

\footnotetext{
10 Астахова В.I. Розробка нової освітньої політики як найважливіша умова модернізації сучасної освіти. Вісник Харківського національного університету імені В.Н. Каразіна. 2016. ВиП. 37. С. $204-212$.
} 
coordination of goals and interests, valuable orientations and partners' needs.

3. The principle of humanization and psychology of the HEI's activity is based on the paradigm of student-centered, humanistic outlook and respect for the personality of all participants in the educational process. In accordance with this principle, the student is considered not as a means of goals implementation, but as the ultimate aim to achieve all these what university is for. At the same time, this very principle is the most important means for reaching the final result of educational activities. Hence, the main condition for the University's successful activities is the individualization of training, the development of methods of individual work in order to maximize the disclosure of personal qualities and potential opportunities of each student. This principle requires the implementation of existing laws and norms of morality, respect for the traditions of the native Alma mater, psychological competence and intelligence of all heads of educational units, teachers, teaching auxiliary staff, students.

Unfortunately, in the majority of scientific and pedagogical workers there is insufficient experience of humanistic communication, active participation in management, personal responsibility for the results of collective labor, where difficulties arise from, in solving many problems facing the university. The pedagogy of partnership, cooperation, mutual understanding and trust, mutual respect and interaction of all participants in the educational process should be the cornerstone of the implementation of this principle.

4. Step by step principle, the principle of continuity and promise - is connected with universal Hegelian laws that are manifested in all spheres of society's life, and is based on the unconditional necessity to analyze and make the most of the legacy of the past, the experience of the present, real possibilities and prospects for the future.

Today there is no doubt that the future system of university education needs a radical revision of most ideas about traditional educational practices, which corresponded to the social order of the era of industrial 
society - the preparation of a highly skilled person, a professional in a particular field of work. The content of education, where the main idea was the knowledge of the world and its subordination to the causal relationships that open up to a person in knowledge suitable for solving problems in standard situations, now contradicts the conditions of dynamism, instability and ambiguity of the world. The search for new models, oriented on creativity, acquisition of knowledge activity and the upbringing of high moral principles, become the actual tasks of practice and modern science.

Implementation of the concept of continuous education - one of the most effective ways of forming competent professionals capable of withstanding competition on the labor market. It is the continuous education designed to ensure the harmonious development of the student's individual, to individualize the educational process, to raise the conscious need of each student in raising the level of their competencies. An important feature of continuous education is its orientation towards the future, in solving problems of the development of society through the formation of professional and general cultural competence in the process of learning.

5. Principle of competence and participation in scientific activity. One of the most important requirements of the new paradigm of education is the orientation towards the education of self-esteem and freedom, the formation and development of professional and general cultural competencies. This leads to the transformation of content, the change of methods, tools and organizational forms of the educational process, and especially the revision of the values of education as a social and cultural phenomenon.

New situation has qualitatively changed the essence of professional competence. The emphasis has shifted from the substantive (technological) knowledge and skills used in solving operational tasks in the direction of conceptual, poly-professional skills and skills that enable them to realize strategic objectives and successfully incorporate into the development of innovations. An important professional competence was the ability to act 
in extreme, stressful, non-standard situations. Thus, professional competence has become more autonomous in relation to specific demands of the labor market. At the same time, the range of competences that "serve" professional competence and non-professional life of a person has expanded: communicative, social, economic, discursive and other competencies, are closely interconnected. Communicative competence as extra functional earns a particular importance, the role of auto-competence increases, therefore, the availability of adequate ideas about oneself, their qualities, abilities, goals and motives of activity grows. This means that the content and process of learning should be aimed at the formation of each student's abilities and qualities that guarantee the susceptibility to everything new, cause the internal need to continually deepen their culturally and professional knowledge, set learning for life, be able to adequately respond to professional problems and life situations. The new economy forces us to give up narrow specialization in favor of interdisciplinary knowledge and versatile competencies. The labor market requires professionals who can quickly transform themselves, make the right decisions and work effectively in a multicultural environment.

Higher education is not only a process of acquiring and assimilated information on a specialty, students need to be taught to think, to learn to study. This requires classroom classes and personal contacts between students and the faculty. However, in order to provide a competent approach to student learning, the teacher must possess the necessary competences himself, which, unfortunately, does not always take place in educational practice.

The professionalism of the teaching staff, their readiness for scientific and pedagogical activities involves the effective possession of the three main competencies: scientific subject, psychological and pedagogical and social and humanitarian. The teacher's transition from performing the functions of the translator of knowledge to the functions of the organizer, the inspirer, the coordinator, the tutor presupposes the formation of the relevant professional qualities and the professional-pedagogical position, which is based on understanding the goals of modern higher education, the 
mechanisms of professional and personal development, and methods of pedagogical management. As one of the main factors of the success of the reform is the commitment and attraction of scientific and pedagogical workers, their personal interest in the new results of their work is necessary. Given the fact that in the coming decades the competitive advantages of developed countries and regions will provide a paradigm of human development, an important condition for achieving results is the humanistic outlook of teachers, the belief in human capacity, the possession of personally oriented technologies for managing the professional development of students. In connection with this, the requirements for the research activities of teachers, the functioning of scientific schools are increasing, and interest in broad involvement in the teaching of scientists working in the research structures, leading specialists from different fields of production and business is growing. Innovative educational process involves the active participation of students in research work. World experience shows that any attempts to provide a high-quality educational process without the development of scientific research is doomed to failure, as it limits the creative possibilities of both teachers and students, leads to self-restraint and stagnation.

6. The principle of collectivism and team work - ensures the creation of the unique atmosphere of mutual understanding and cooperation, mutual support and interest in the success of each other, which is inherent in the family relationship of unity, warmth and attention to each member of the family. Formation of a co-thinker group, people who work in the field of achieving a single goal does not in any way imply a leveling of bright personalities among teachers and students. On the contrary, this process is impossible without stimulating the interested creative activity of everyone, without creating the maximum conditions for their development, material and moral stimulation of the creative work of the individual in the name of establishing the credibility of the entire labor collective. Therefore, among the main priorities for the future, it is necessary to focus on working with the most gifted and motivated students, developing their individual educational trajectories, special programs, creative tasks. 
Based on collectivist principles, patriotism is actively formed as a loyalty to the ideals and traditions of the higher, as the trembling attitude to university symbols (emblem, flag, anthem, memorable signs, etc.), as the willingness to come to the aid of each other and the collective as a whole in any situation. Collectivism is the result of purposeful educational work of educational and extra-curricular units of HEI.

7. Principle of creative learning. By building a model of higher education for an innovative economy, experts point out that "the culture of assimilation should be replaced by a culture of search and renewal"11. In other words, modern trends require the redistribution of the proportion of used teaching methods, oriented towards students' reproductive, productive, creative and researching activities. Educational technologies that allow the training of highly skilled professionals capable of creativity are based on the inclusion in the educational process of elements of research, close to the actual activities of a future specialist. For organization of the learning process in the HEI, as in the business sector, it is important to disseminate project forms of work that can be applied not only within the framework of individual training sessions, but also in the mode of mobile project groups. Thus, the principle of creative learning involves the productivity of cognitive students' activity, the production of subjective and objectively new knowledge, technologies, etc., joint creative search, the use of interactive and project methods, as well as the context of learning, that is, imitating the solution of real professional problems.

8. Principle of activation of personal mechanisms of professional formation. An important requirement for the educational process is the consistent stimulation of the personal development of each student, the activation of the personal mechanisms of his professional development. Since the qualities of a competent professional can not be formulated from the outside and in a step-by-step controlled work, a high level of student autonomy is required, support for self-determination of the student in relation to the work being carried out and self-actualization in it. A student

\footnotetext{
${ }^{11}$ Терлоу К. Образование в перспективе. Первое сентября. 2012. 24 ноября. С. 1.
} 
as a person and a future professional develops only in that activity, which is stimulated by internal motives, carried out with curiosity and enthusiasm. In this case, he shows his potential, improves the ability to manage himself and his activities, achieve planned results. It is no coincidence that the student's motivation, interest, and abilities are considered to be the key, most valuable resource of education. It is this case a personal resource which allows "to run" the mechanisms of professional development, gives the most value, in terms of innovation economy, educational outcomes.

9. Principle of problem-oriented approach for management activities. Describing the modern management model one must take into an account that the university is a quite specific type of educational institution, the results of which depends not only on the formal features management system (legal form, structure, documentation, etc.), But the system of values which are promoted under this team, where the management activity relies on. Non standard, problem existing in education, the necessity to search for non-trivial ways of their solution is determined by the rejection of the principles of classical theory and the transition to professional management, based on the modern theoretical basis, a new management paradigm. One of the peculiarities of this paradigm is standing by from managerial rationalism - the initial belief that the success of any organization (including HEI) is determined primarily by a rational organization, a clear division of functional responsibilities, the efficient use of all kinds of resources. Under such a traditional approach, any organization is considered to be a "closed" system whose goals and objectives are presumed to be predetermined and remained, as well as other conditions of activity, sufficiently stable over a long period of time. The basis of the strategy of such organizations is the continuous growth, increase of quantitative indicators, while in the mechanisms of management, the effective control of all types of activities is crucial. The new philosophy of management is based on system and situational approaches. Any HEI is seen as an open system: the main reasons for its success are not inside but outside of it. The success is associated with how 
well the university adapts to the external environment: economic, scientific and technical, socio-political, cultural, etc. This determines the need for a situational approach, according to which the construction of the control system is nothing but the organization's response to the various external influences by nature and some other characteristics of its organizational context, in particular, the dependence on the quality of human resources. The new situation in the world, especially in the field of higher education, today depends on two factors: uncertainty and orientation towards the future. And under the uncertainty it is understood not a separate social fact of the instability of living space, it is about a fundamental uncertainty of key parameters of social sphere. Philosophers and social scientists (G. Haken, P. Glensdorf, K. George, R. Dafe, J. Coglioty, S. Kurdjumov, X. Maindreih, K. Maintser, L. Rosenfeld, M. Studler and others.) speak about creating the new, synergistic world, opened and difficult but organized, continuously emerging and changing. It emphasizes that the world is unstable, multivariate and alternative, with the pace and direction of development which are not unambiguously specified. Hence, a new understanding of the problem of managing difficultly organized systems: orientation is not so much about the director's desire, but based on the own tendencies of the development of these systems, as well as the assumption of the possibility of existence of zones free of control.

Thus, given the complexity of the social environment, a variety of objectives, content, forms of organization and technology, the changes in the professional culture of teaching staff, any university, first had to take care of flexibility and adaptability of their management systems. Organizational-managerial mechanisms adapt to the identification of new problems and the development of new solutions more than the control which is already taken ${ }^{12}$. The challenge is to develop targeted management of a special type, namely problem-oriented, designed to ensure the effective implementation of large-scale, mass innovations that allow to move from sporadic measures to create a sustainable mechanism for the

\footnotetext{
12 Астахова В.И., Астахова Е.В. Проблемно-ориентированное планирование как определяющий элемент системы управления в вузе. Харьков : Изд-во НУА, 2015. 351 с.
} 
orientation of higher education for a long-term goal and objectives of innovative educational policy. To implement this approach, the basic ideas of all members of the team should be changed. Each of them must be formed a fundamentally new attitude to organizational culture, which requires a long, carefully thought-out work with staff, taking into an account the features of one or another HEI, the specific situation in the country and the world, general trends in society and, first of all, the industry of education.

10. The principle of the organic combination of the democratic foundations of the university with the appropriate elitism of the proposed higher education, which is understood as an exclusively high level of professional responsibility and competence. Elitism, in our interpretation, is not the choice of the different criteria (external tests), the most intelligent students, highly qualified and professionally competent teachers who can grow "pearls of grains", open up opportunities and talents due to the high level and quality of teaching, thanks to the love of those who are taught, and what they teach. Formation of such an attitude of scientific and pedagogical workers in their activity and duty should become the cornerstone of the innovative educational policy of the modern university.

\section{SUMMARY}

So, an important factor in the growth of human capital in Ukraine, the dynamic development of the economy and society as a whole is the reform of education, in particular the university. This requires overcoming a number of problems, among which the most relevant are: a significant increase in the number of HEIs and a rapid increase in the total number of students by 2008, the stabilization and gradual reduction of these indicators since 2010; mismatch of the structure of training specialists to the real needs of the economy; a sharp decline in the quality of higher education; excessive load on one rate (by 2014900 hours a year) and a decrease in the status of scientific and pedagogical workers in the society; insufficient financing and updating of material and technical base; the separation of scientific research from practical implementation; slow pace of integration 
into the European and world scientific and educational space, etc. We highlight the priority directions of the reform of the national higher education and outline the common basic principles of the University's innovative educational policy. Only by overcoming the critical situation, changing the content, forms and methods of organizing the educational process of the HEI, creating fundamentally new scientific, informational, technological, teaching and methodological support, improving the professional pedagogical culture of teachers, where higher education will be able to answer the challenges of time and become an effective sustainable resource for the development of both an individual region and the country as a whole.

\section{REFERENCES}

1. Астахова B.I. Розробка нової освітньої політики як найважливіша умова модернізації сучасної освіти. Вісник Харківського національного університету імені В.Н. Каразіна. 2016. Вип. 37. C. 204-212.

2. Астахова В.И., Астахова Е.В. Проблемно-ориентированное планирование как определяющий элемент системы управления в вузе. Харьков : Изд-во НУА, 2015. 351 с.

3. Вища освіта України. Центр міжнародних проектів НДІ прикладних інформаційних технологій «Євро Освіта». URL : http://www.euroosvita. net/prog/print.php/prog/print

4. Державна служба статистики України : Вищі навчальні заклади. URL : http://www.ukrstat.gov.ua/ operativ/operativ2005/osv_rik/ osv_u/vuz_u.html

5. Зарплата українських вчителів - одна 3 найнижчих у світі URL : http://www.unian.ua/society/838832-zarplata-ukrajinskih-vchitelivodna-z-naynijchih-u-sviti.html

6. Макаренко А.Ю. Кадровий аспект проблеми формування ІКТ-компетентності викладачів ЗВО. Наукова скарбниця освіти Донеччини. 2013. № 1 (14). С. 82-88. 
7. Право на освіту та права освітян: теорія і практика в Україні: аналітичний звіт за результатами громадського моніторингу. URL: http://eura.org.ua/wp-content/uploads/2010/01/ERA_Vidrodzhannya_ Право-на-освіту-та-права-освітян_Аналітичний-звіт_-червень2018.pdf

8. Про вищу освіту. Закон України № 1556-VII від 01.07.2014. URL : http://zakon4.rada.gov.ua/laws/show/1556-18

9. Про освіту: Закон України від 05.09.2017 p. № 2145-VIII. URL : http://zakon.rada.gov.ua/laws/show/2145-19

10. Терлоу К. Образование в перспективе. Первое сентября. 2012. 24 ноября. С. 1-2.

\section{Information about the author: Orshansky L. V.}

Doctor of Pedagogical Sciences, Professor, Head of the Department of Technological and Professional Education, Drogobych Ivan Franko State Pedagogical University 4/6, M. Hrushevsky str., Drohobych, Lviv region, 82107, Ukraine 